\title{
The effect of hormone therapy on bone mineral density and cardiovascular factors among Iranian female athletes with amenorrhea/oligomenorrhea: A randomized clinical trial
}

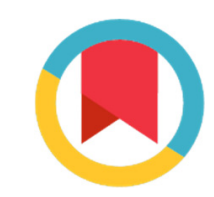

\author{
Haleh Dadgostar ${ }^{1}$, Ghazaleh Soleimany ${ }^{1 *}$, Shafieh Movaseghi ${ }^{2}$, Elham Dadgostar ${ }^{3}$, Sara Lotfian ${ }^{1}$
}

Received: 20 Nov $2016 \quad$ Published: 1 Apr 2018

\begin{abstract}
Background: Functional hypothalamic menstrual disorder (FHMD) has a destructive effect on the athlete's bone mineral density and cardiovascular system. Utilizing hormone replacement therapy to treat FHMD in athletes is controversial.

This study was conducted to examine the effect of hormone therapy on bone density and the cardiovascular system of professional female athletes with FHMD.

Methods: In this study, 18 female athletes with at least a 2- year history of FHMD were recruited in a 9-month single blind randomized clinical intervention (RCT) and randomly classified into 2 groups: the oral contraceptive pills (OCP) group, who received a lowdose combined oral contraceptive (OC) containing $30 \mu \mathrm{g}$ ethinyl estradiol and $150 \mu \mathrm{g}$ levonorgestrel $(\mathrm{n}=10)$, and the control group (n $=8$ ). Bone mineral densitometry (BMD) and certain cardiovascular risk factors were measured before and after the 9-month trial. The Chi square test was used to compare the quantitative and qualitative results.

Results: Bone mineral density did not change significantly in either group. Very low density lipoprotein (VLDL) $(p=0.035)$ and Apolipoprotein B (Apo B) $(\mathrm{p}=0.04)$ reduced significantly in the OCP group. An increase was observed in the serum levels of Apolipoprotein A (Apo A) ( $\mathrm{p}=0.01)$ in the control group. Changes in the Apo B to Apo A ratio was significant in both groups (OCP group: $p=0.018$, control group: $p=0.040$ ). No significant changes were observed in the other measured factors.

Conclusion: Although the administration of estrogen did not significantly increase bone mineral density, it had positive effects on the cardiovascular system and lipid profile.
\end{abstract}

Keywords: Functional hypothalamic menstrual disorder (FHMD), Hypoestrogenism, Bone density, Cardiovascular risk factor, Hormone therapy, OCP (oral contraceptive pills)

Copyright $\odot$ Iran University of Medical Sciences

Cite this article as:Dadgostar H, Soleimany Gh, Movaseghi Sh, Dadgostar E, Lotfian S. The effect of hormone therapy on bone mineral density and cardiovascular factors among Iranian female athletes with amenorrhea/oligomenorrhea: A randomized clinical trial. Med J Islam Repub Iran. 2018(1 Apr);32:27. https://doi.org/10.14196/mjiri.32.27

\section{Introduction}

Female athlete triad is defined as a mutual relationship between energy availability, menstrual function, and bone mineral density (BMD) in female athletes (1). Ten years ago, the triad was defined again as a syndrome with the following 3 components: low energy availability with or without an eating disorder, functional hypothalamic amenorrhea, and osteoporosis $(2,3)$. The reduction of available energy with or without an eating disorder can not only disrupt an individual's health, but also can affect

Corresponding author: Dr Ghazaleh Soleimany,ghazaleh.soleimany@gmail.com

1. Department of Sports and Exercise Medicine, Rasoul-e-Akram Hospital, Iran University of Medical Sciences, Tehran, Iran.

2. Rheumatology Research Center, Tehran University of Medical Sciences, Tehran, Iran.

3. Sports Medicine Federation of Islamic Republic of Iran, Tehran, Iran. her cardiovascular, endocrine, genital, skeletal, gastrointestinal, and nervous systems (1). In the newly proposed triad model, the endpoint of each component is represented as its clinical or subclinical status, meaning that the healthy status of the individual is the optimized state of each component, and the pathologic endpoint is the syndrome itself $(2,3)$.

Expert individuals, who work in groups in the IOC, have given a more general title to the triad: 'Relative En-

$\uparrow$ What is "already known" in this topic:

Female athletes with menstrual dysfunction are at risk of low bone density. It seems that these athletes are prone to early cardiovascular disease. Hormone therapy is one of the recommended treatments for these athletes.

\section{$\rightarrow$ What this article adds:}

Bone density of female athletes was not increased significantly after a 9-month hormone therapy. However, some cardiovascular factors such as VLDL and apo B, predictors of cardiovascular disease, improved by this type of treatment. 
ergy Deficiency in Sport (RED-S)'. RED-S includes physiologic functions such as metabolic rate, protein synthesis, bone health, immunity, menstrual syndrome, and cardiovascular health that may be impaired in either gender (4). In a published report in 2009 (5), it was found that approximately $9 \%$ of Iranian female elite athletes have amenorrhea/or oligomenorrhea.

Low level of estrogen is associated with a suppressed hypothalamic-pituitary-adrenal (HPA) axis. Suppressing the HPA can disrupt the increase in bone density throughout adolescence and can also disrupt the maintenance of bone density throughout the individual's life.

Chronic hypoestrogenism, often seen in athletes suffering from amenorrhea/oligomenorrhea, is considered one of the main reasons contributing to reduced bone mineral density in women of all ages (6). Estrogen plays a key role in the skeletal hemostasis and maintains a balance between bone resorption and formation by inhibiting osteoblast apoptosis and stimulating osteoclast apoptosis. In other words, estrogen promotes bone formation and prevents its resorption; hence, its low levels have adverse effects on BMD (7-9). In women receiving regular physical exercise, both past and current menstrual patterns are important in predicting estimates of femoral neck BMD (10). The majority of previous studies have reported lower bone mineral density in professional female athletes with amenorrhea/oligomenorrhea compared with that of those who have normal menstrual cycles. In most individuals, who practice weight-bearing sports, the bone density is $12 \%$ to $15 \%$ higher than in non-athletes. Based on recent definitions 'low BMD' is recognized as a BMD Z score $\leq$ 1.0 as well as a history of hypoestrogenism, nutritional deficiencies, and/or stress fracture (11).

A few studies have assessed the effect of pharmacologic interventions on BMD changes among this population. On the other hand, we assumed that failure to increase BMD among young athletes could be a precursor of some complications such as stress fracture and low BMD; therefore, we aimed at comparing the effect of calcium plus vitamin D supplementation with estrogen therapy on BMD changes in this group of athletes.

Apart from lowering bone mineral values, low estrogen has negative effects on the female athlete's health. The main cardiovascular changes reported in the athletes with amenorrhea are the increased risk of developing early cardiovascular diseases in these individuals; no longitudinal study has ever been conducted in this regard $(12,13)$. In postmenopausal women, hypoestrogenism is linked with certain cardiovascular-related clinical sequels $(12,13)$. About $25 \%$ to $50 \%$ of the protective effect of estrogen on the heart is secondary to its positive effects on serum lipid profile (14). The oxidative changes in the lipids of vascular membrane may affect the production and bioactivity of nitric oxide, resulting in endothelial malfunction (15). In postmenopausal women, reduced estrogen levels are associated with changes in lipid metabolism(16). These changes are also seen in other hypoestrogenism status such as anorexia nervosa(17). Female athletes with complaint of amenorrhea are also at risk for these health concerns due to chronic hypoestrogenism. Despite being physically active, these women were found to have impaired plasma lipid profile such as high serum levels of triglyceride and cholesterol compared with female athletes with eumenorrhea (18). As a result, chronic hypoestrogenism may increase the risk of early heart disease in young female athletes despite the fact that they exercise regularly.

Few studies have been conducted on the effects of estrogen treatment of the athletes with amenorrhea on their cardiovascular system. Previous studies have revealed the positive effects of endogenous estrogen on the cardiovascular system; however, exogenous estrogen and hormone replacement therapy were reported to have negative effects on postmenopausal women(12). Thus, more studies should be conducted to assess the cardiovascular effects of treating hypoestrogenism with estrogen in female athletes with menstrual disorders.

Hypoestrogenism in athletes with FHMD may lead to glucose intolerance. According to literature, menopause is associated with an increased risk of developing glucose intolerance and Type 2 diabetes, and hypoestrogenism is the most important factor contributing to this finding (19). Glucose intolerance, reduced sensitivity to insulin and hyperinsulinemia, increase serum glucose levels and consequently the risk of coronary artery disease (CAD) (20). Several researches have recommended that hormone replacement therapy (HRT) may increase sensitivity to insulin and glucose tolerance (21). Estrogen replacement changes serum levels of lipids and lipoproteins, resulting in reduced cardiovascular diseases (22); its other positive effects may be due to its effects on insulin resistance. Several studies have tried to point out the relationship between estrogen treatment and glucose hemostasis in nondiabetic females; controversial results were reported (23).

The number of studies that have assessed the effect of pharmacologic intervention on cardiovascular system is even less than studies on BMD changes. Therefore, the present study was designed to assess bone mineral density values and the serum levels of factors such as fibrinogen, homocystein, and lipids in female athletes with FHMD before and after receiving oral contraceptive pills for a 9month treatment course to evaluate the effect of estrogen therapy on different hypoestrogenism-related complications in FHMD female athletes.

\section{Methods \\ Data}

A 9-month single blind randomized clinical trial (RCT) was conducted on 18 female athletes with at least a 2-year history of functional hypothalamic menstrual dysfunction (FHMD). This study was the continuation of the research conducted by Dadgostar et al. on the Iranian female professional athletes started in 2007. In that study among all Iranian elite female athletes of 34 different exercise fields, 56 female athletes were diagnosed with FHMD (3). This study has been approved by the ethics committee of Iran University of Medical Sciences (code number: 927) and conforms to the ethical standards set forth by the Global Medical Community's Declaration of Helsinki.

All patients $(n=56)$ diagnosed with FHMD in the previous study were invited to participate in the study after 
about $25.55(\mathrm{SD}=6.15)$ months

First, one of the examiners (G.S) called and asked athletes about their previous problems, related complications, andany treatment received. As displayed in Fig. 1, athletes were excluded from the study if any of the following criteria was present: (1) becoming eumenorrheic during the time between the 2 researches; (2) being a smoker; (3) taking any form of hormonal therapy or medications affecting bone metabolism between the 2 studies; (5) reducing the intensity of exercise and not participating in sport specific training sessions (at least 2 times per week); (6) having a positive history of polycystic ovarian syndrome; (7) suffering from chronic diseases including hyperprolactinemia and thyroid disorders; and (8) having contraindications to the OCP use.

A total of 18 female athletes met the inclusion criteria, signed the ethical consent form, and accepted to participate in the trial. Then, they were randomly assigned into 2 groups using the computer-generated table of random numbers (Excel, Microsoft, Rounded program): the OCP group $(n=10)$ and the control group $(n=8)$. The OCP group received a low-dose combined oral contraceptive (30 $\mu \mathrm{g}$ ethinyl estradiol $+150 \mu \mathrm{g}$ levonorgestrel) for 9 months. The control group, on the other hand, did not receive OCP. All the participants, either from the case or from the control group, received $1000 \mathrm{mg} / \mathrm{d}$ calcium and $400 \mathrm{IU} / \mathrm{d}$ vitamin D. The participants were asked not to take any hormonal drugs or medications affecting bone metabolism during the study period. All athletes were recommended to use the suggested diet based on the intensity and duration of exercises.

The individuals were followed- up by telephone calls every month to ensure that they used the prescribed drugs regularly and also that their drug compliance and the occurrence of possible side effects would be studied. The participants were visited every 3 months. Iranian registry of clinical trials number of this research is IRCT138904024251N1.

\section{Measurement}

The following variables were tested before and 9 months after the initiation of the study:

A. Laboratory factors including blood glucose, lipid profile, and inflammatory markers were measured.

1. Blood glucose was evaluated by measuring fasting blood glucose (FBS) and hemoglobin $(\mathrm{Hb}) \mathrm{A} 1 \mathrm{C}$ (Cobas mira kit: Randox).

2. Lipid profile included total cholesterol, high density lipoprotein (HDL), low density lipoprotein (LDL), very low density lipoprotein (VLDL), triglyceride (TG), and apolipoprotein (Apo) A and apo B by Beckman CX-3 biochemical autoanalyzer (Pishtaz Teb kit for HDL and LDL; Parsazmoon for TG and Chol; and Randox for Apo A and Apo B).

\begin{tabular}{|c|c|c|c|c|c|c|}
\hline \multirow[t]{2}{*}{ Group } & \multicolumn{2}{|c|}{$\begin{array}{l}\text { OCP } \\
(\mathrm{n}=8)\end{array}$} & \multicolumn{2}{|c|}{$\begin{array}{l}\text { Ca- D } \\
(n=5)\end{array}$} & \multicolumn{2}{|c|}{$\begin{array}{l}\text { TOTAL } \\
(\mathrm{n}=13)\end{array}$} \\
\hline & $\begin{array}{c}\text { Before } \\
\text { the intervention }\end{array}$ & $\begin{array}{c}\text { At the end } \\
\text { of intervention }\end{array}$ & $\begin{array}{c}\text { Before } \\
\text { intervention }\end{array}$ & $\begin{array}{l}\text { At the end of } \\
\text { intervention }\end{array}$ & $\begin{array}{c}\text { Before } \\
\text { intervention }\end{array}$ & $\begin{array}{l}\text { At the end of } \\
\text { intervention }\end{array}$ \\
\hline $\begin{array}{l}\text { Spine bone } \\
\text { density }\end{array}$ & $\begin{array}{c}1.017 \\
(\mathrm{SD}=0.179)\end{array}$ & $\begin{array}{c}1.020 \\
(\mathrm{SD}=0.179)\end{array}$ & $\begin{array}{c}1.021 \\
(\mathrm{SD}=0.071)\end{array}$ & $\begin{array}{c}1.004 \\
(\mathrm{SD}=0.070)\end{array}$ & $\begin{array}{c}1.018 \\
(\mathrm{SD}=0.143)\end{array}$ & $\begin{array}{c}1.014 \\
(\mathrm{SD}=0.137)\end{array}$ \\
\hline $\begin{array}{l}\text { Femur bone } \\
\text { density }\end{array}$ & $\begin{array}{c}0.829 \\
(\mathrm{SD}=0.137)\end{array}$ & $\begin{array}{c}0.832 \\
(\mathrm{SD}=0.151)\end{array}$ & $\begin{array}{c}0.830 \\
(\mathrm{SD}=0.102)\end{array}$ & $\begin{array}{c}0.839 \\
(\mathrm{SD}=0.111)\end{array}$ & $\begin{array}{c}0.829 \\
(\mathrm{SD}=0.120)\end{array}$ & $\begin{array}{c}0.835 \\
(\mathrm{SD}=0.132)\end{array}$ \\
\hline
\end{tabular}

Table 2. Comparison of lipid profile levels in different groups

\begin{tabular}{|c|c|c|c|c|c|c|}
\hline \multirow{3}{*}{ Group } & \multicolumn{2}{|c|}{$\begin{array}{l}\mathrm{OCP} \\
(\mathrm{n}=8)\end{array}$} & \multicolumn{2}{|c|}{$\begin{array}{l}\text { Ca- D } \\
(n=5)\end{array}$} & \multicolumn{2}{|c|}{$\begin{array}{c}\text { Total } \\
(\mathrm{n}=13)\end{array}$} \\
\hline & $\begin{array}{c}\text { Before } \\
\text { intervention }\end{array}$ & $\begin{array}{l}\text { At the end of } \\
\text { intervention }\end{array}$ & $\begin{array}{l}\text { Before interven- } \\
\text { tion }\end{array}$ & $\begin{array}{c}\text { At the end } \\
\text { of intervention }\end{array}$ & $\begin{array}{c}\text { Before } \\
\text { intervention }\end{array}$ & $\begin{array}{l}\text { At the end of } \\
\text { intervention }\end{array}$ \\
\hline & 69.29 & 69.62 & 98.80 & 78.4 & 81.58 & 73.00 \\
\hline TG & $(\mathrm{SD}=18.52)$ & $(\mathrm{SD}=21.99)$ & $(\mathrm{SD}=55.26)$ & $(\mathrm{SD}=39.49)$ & $(\mathrm{SD}=39.09)$ & $(\mathrm{SD}=28.66)$ \\
\hline Total & 191.86 & 170.75 & 159.60 & 151.80 & 178.42 & 163.46 \\
\hline Cholesterol & $(\mathrm{SD}=41.55)$ & $(\mathrm{SD}=38.01)$ & $(\mathrm{SD}=17.57)$ & $(\mathrm{SD}=26.32)$ & $(\mathrm{SD}=37.97)$ & $(\mathrm{SD}=34.14)$ \\
\hline LDL & $\begin{array}{c}86.43 \\
(\mathrm{SD}=18.72)\end{array}$ & $\begin{array}{c}101.12 \\
(\mathrm{SD}=27.94)\end{array}$ & $\begin{array}{c}78.20 \\
(\mathrm{SD}=17.57)\end{array}$ & $\begin{array}{c}83.80 \\
(\mathrm{SD}=31.40)\end{array}$ & $\begin{array}{c}83.00 \\
(\mathrm{SD}=17.92)\end{array}$ & $\begin{array}{c}94.46 \\
(\mathrm{SD}=29.34)\end{array}$ \\
\hline HDL & $\begin{array}{c}50.86 \\
(\mathrm{SD}=10.37)\end{array}$ & $\begin{array}{c}46.87 \\
(\mathrm{SD}=6.96)\end{array}$ & $\begin{array}{c}51.00 \\
(\mathrm{SD}=11.98)\end{array}$ & $\begin{array}{c}50.40 \\
(\mathrm{SD}=11.89)\end{array}$ & $\begin{array}{c}50.92 \\
(\mathrm{SD}=10.53)\end{array}$ & $\begin{array}{c}48.23 \\
(\mathrm{SD}=8.86)\end{array}$ \\
\hline VLDL & $\begin{array}{c}51.51 \\
(\mathrm{SD}=22.49) \\
\end{array}$ & $\begin{array}{c}22.75 \\
(\mathrm{SD}=13.59) \\
\end{array}$ & $\begin{array}{c}29.75 \\
(\mathrm{SD}=18.82) \\
\end{array}$ & $\begin{array}{c}17.60 \\
(\mathrm{SD}=7.96) \\
\end{array}$ & $\begin{array}{c}42.80 \\
(\mathrm{SD}=22.92) \\
\end{array}$ & $\begin{array}{c}20.77 \\
(\mathrm{SD}=11.65) \\
\end{array}$ \\
\hline \multirow[t]{2}{*}{ Group } & \multicolumn{2}{|c|}{$\begin{array}{l}\text { OCP } \\
(n=8)\end{array}$} & \multicolumn{2}{|c|}{$\begin{array}{l}\text { Ca- D } \\
(n=5)\end{array}$} & \multicolumn{2}{|c|}{$\begin{array}{c}\text { Total } \\
(\mathrm{n}=13) \\
\end{array}$} \\
\hline & $\begin{array}{c}\text { Before } \\
\text { intervention }\end{array}$ & $\begin{array}{c}\text { At the end } \\
\text { of intervention }\end{array}$ & $\begin{array}{c}\text { Before } \\
\text { intervention }\end{array}$ & $\begin{array}{c}\text { At the end } \\
\text { of intervention }\end{array}$ & $\begin{array}{c}\text { Before } \\
\text { intervention }\end{array}$ & $\begin{array}{c}\text { At the end } \\
\text { of intervention }\end{array}$ \\
\hline Apo A & $\begin{array}{c}162.17 \\
(\mathrm{SD}=46.31)\end{array}$ & $\begin{array}{c}166.25 \\
(\mathrm{SD}=23.74)\end{array}$ & $\begin{array}{c}113.18 \\
(\mathrm{SD}=20.31)\end{array}$ & $\begin{array}{c}162.60 \\
(\mathrm{SD}=14.81)\end{array}$ & $\begin{array}{c}139.90 \\
(\mathrm{SD}=43.50)\end{array}$ & $\begin{array}{c}164.85 \\
(\mathrm{SD}=20.13)\end{array}$ \\
\hline Apo B & $\begin{array}{c}91.40 \\
(\mathrm{SD}=11.87)\end{array}$ & $\begin{array}{c}67.25 \\
(\mathrm{SD}=16.46)\end{array}$ & $\begin{array}{c}68.06 \\
(\mathrm{SD}=20.23)\end{array}$ & $\begin{array}{c}59.40 \\
(\mathrm{SD}=18.58)\end{array}$ & $\begin{array}{c}79.73 \\
(\mathrm{SD}=19.90)\end{array}$ & $\begin{array}{c}64.23 \\
(\mathrm{SD}=17.00)\end{array}$ \\
\hline $\begin{array}{l}\text { Apo B/ } \\
\text { Apo A }\end{array}$ & $\begin{array}{c}0.63 \\
(\mathrm{SD}=0.19)\end{array}$ & $\begin{array}{c}0.44 \\
(\mathrm{SD}=0.14)\end{array}$ & $\begin{array}{c}0.62 \\
(\mathrm{SD}=0.21)\end{array}$ & $\begin{array}{c}0.37 \\
(\mathrm{SD}=0.13)\end{array}$ & $\begin{array}{c}0.63 \\
(\mathrm{SD}=0.19)\end{array}$ & $\begin{array}{c}0.40 \\
(\mathrm{SD}=0.12)\end{array}$ \\
\hline
\end{tabular}


3. Fibrinogen and hemocystein as the inflammatory markers (Enzymatic Immunosorbent Assay (ELIZA)).

B. Bone mineral density (BMD, gram per square centimeter) at lumbar spine (L1-L4) and femoral neck were measured by dual energy X-ray absorptiometry (DXA) using a Hologic densitometer (Hologic Discover QDR). The results have been described according to Hologic standards (driven from the NHANSE III study) (20). The assessment has been performed with a same device for all the participants.

\section{Statistical Analysis}

Quantitative results are based on mean and standard deviation and the qualitative results are reported using frequency $\mathrm{t}$ test. Chi square test was used to compare the quantitative and qualitative results. SPSS software (Version 17) was used for data analysis. A $p<0.05$ was considered statistically significant.

\section{Results}

Based on the results depicted in Table 1, there was no significant difference between BMD values at femoral neck within the groups or after the intervention. BMD values at lumbar spine showed a slight increase $(0.3 \%$ increase in 9 months) in those receiving OCP and a minor decrease in the control group $(1.6 \%$ decrease in 9 months); neither of which, however, was statistically significant.

Our data revealed that the prevalence of VLDL levels higher than $30 \mathrm{mg} / \mathrm{dL}$ was 53\% (7/13), LDL levels higher than $100 \mathrm{mg} / \mathrm{dL}$ was $75 \%(9 / 13)$, and HDL lower than 50 $\mathrm{mg} / \mathrm{dL}$ was $53 \%(7 / 13)$ at baseline in participants of both groups.

As presented in Table 2, there was a significant decrease in VLDL levels in the OCP group ( $p=0.035)$. A nonstatistically significant reduction, however, was reported in serum levels of total cholesterol in both groups, particularly those taking OCP. These pills, on the other hand, resulted in a nonsignificant increase in LDL levels. No significant change was observed in HDL and TG levels of either group.

Also, 38\% (5/13) of all participants in both groups had low level of apo A (lower than 120) and all of them had normal apo B levels at baseline (Table 3). Apo B levels showed a significant decrease in the OCP group $(p=0.04)$. No significant change was observed in apo A levels in the OCP group. However, a significant increase was noted in apo A levels of the control group, who had received $\mathrm{Ca}$ and vitamin $\mathrm{D}$ as the only treatment medication. There was a significant difference between apo B to apo A ratio in both the $\mathrm{Ca}$ and vitamin D and OCP group $(\mathrm{p}=0.040$; 0.018).

A nonsignificant increase in fibrinogen levels and a nonsignificant decrease in HbAlc and homocystein levels were noted in both groups (Table 4).

Moreover, HbA1C level of 23\% (3/13) of participants of both groups was 6 at baseline.

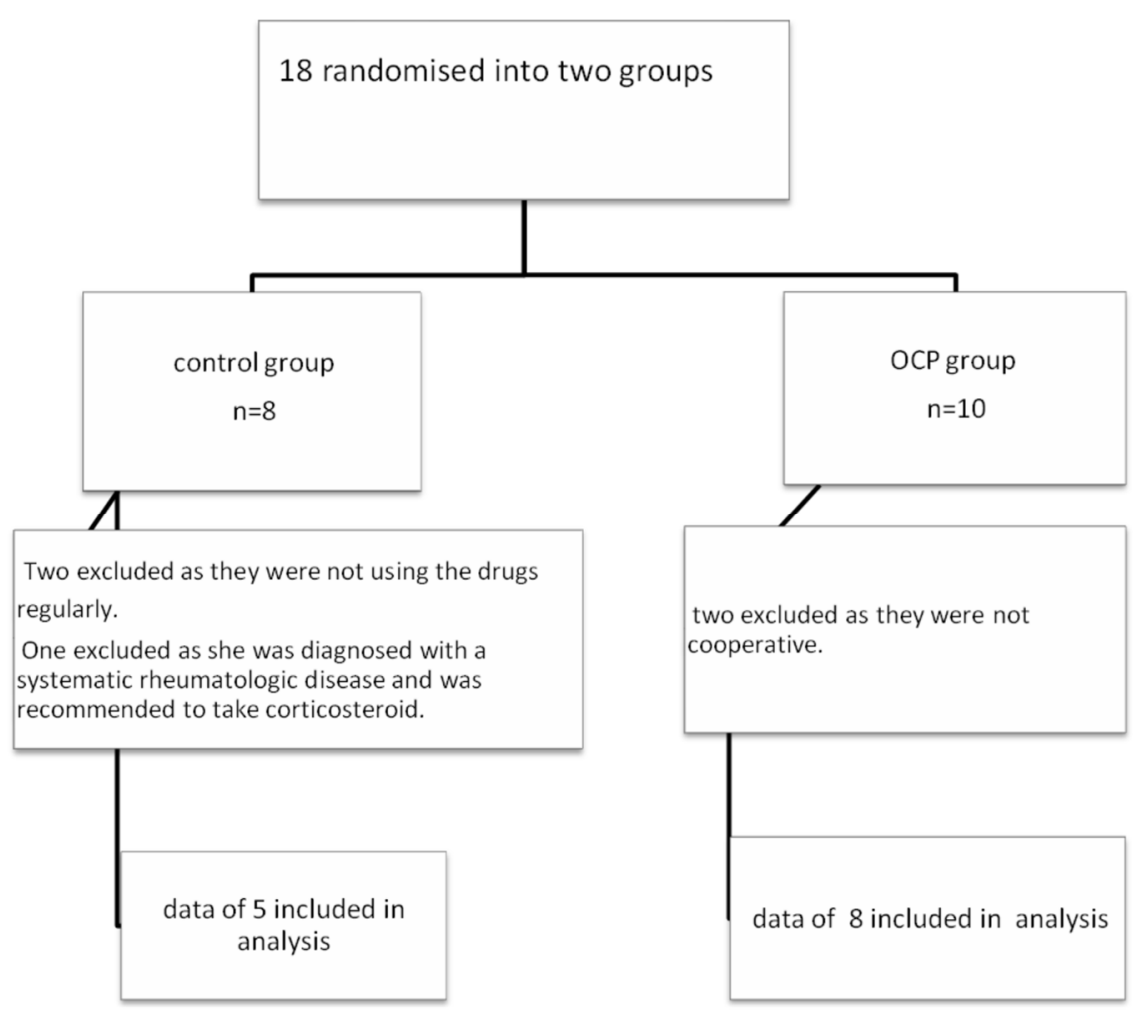

Fig. 1.Flow diagram of participants through the trial 


\begin{tabular}{|c|c|c|c|c|c|c|}
\hline \multirow[t]{2}{*}{ Group } & \multicolumn{2}{|c|}{$\begin{array}{l}\text { OCP } \\
(\mathrm{n}=8)\end{array}$} & \multicolumn{2}{|c|}{$\begin{array}{l}\text { Ca- D } \\
(n=5)\end{array}$} & \multicolumn{2}{|c|}{$\begin{array}{c}\text { Total } \\
(\mathrm{n}=13)\end{array}$} \\
\hline & $\begin{array}{c}\text { Before } \\
\text { Intervention }\end{array}$ & $\begin{array}{c}\text { At the end } \\
\text { of intervention }\end{array}$ & $\begin{array}{c}\text { Before } \\
\text { intervention }\end{array}$ & $\begin{array}{c}\text { At the end } \\
\text { of intervention }\end{array}$ & $\begin{array}{c}\text { Before } \\
\text { intervention }\end{array}$ & $\begin{array}{l}\text { At the end } \\
\text { of intervention }\end{array}$ \\
\hline FBS & $\begin{array}{c}91.60 \\
(\mathrm{SD}=6.88)\end{array}$ & $\begin{array}{c}90.25 \\
(\mathrm{SD}=8.34)\end{array}$ & $\begin{array}{c}87.33 \\
(\mathrm{SD}=10.07)\end{array}$ & $\begin{array}{c}93.00 \\
(\mathrm{SD}=6.12)\end{array}$ & $\begin{array}{c}90.00 \\
(\mathrm{SD}=7.80)\end{array}$ & $\begin{array}{c}91.31 \\
(\mathrm{SD}=7.42)\end{array}$ \\
\hline $\mathrm{HbA1C}$ & $\begin{array}{c}4.92 \\
(\mathrm{SD}=0.72)\end{array}$ & $\begin{array}{c}4.41 \\
(\mathrm{SD}=0.49)\end{array}$ & $\begin{array}{c}5.60 \\
(\mathrm{SD}=0.44)\end{array}$ & $\begin{array}{c}4.88 \\
(\mathrm{SD}=0.61)\end{array}$ & $\begin{array}{c}5.26 \\
(\mathrm{SD}=0.67)\end{array}$ & $\begin{array}{c}4.59 \\
(\mathrm{SD}=0.57)\end{array}$ \\
\hline Homocystein & $\begin{array}{c}10.13 \\
(\mathrm{SD}=2.44)\end{array}$ & $\begin{array}{c}8.50 \\
(\mathrm{SD}=1.99)\end{array}$ & $\begin{array}{c}11.50 \\
(\mathrm{SD}=2.96)\end{array}$ & $\begin{array}{c}8.30 \\
(\mathrm{SD}=0.57)\end{array}$ & $\begin{array}{c}10.75 \\
(\mathrm{SD}=2.64)\end{array}$ & $\begin{array}{c}8.46 \\
(\mathrm{SD}=1.74)\end{array}$ \\
\hline Fibrinogen & $\begin{array}{c}209.20 \\
(\mathrm{SD}=32.76)\end{array}$ & $\begin{array}{c}252.00 \\
(\mathrm{SD}=46.27)\end{array}$ & $\begin{array}{c}219.80 \\
(\mathrm{SD}=52.22)\end{array}$ & $\begin{array}{c}248.00 \\
(\mathrm{SD}=37.20)\end{array}$ & $\begin{array}{c}79.73 \\
(\mathrm{SD}=19.90)\end{array}$ & $\begin{array}{c}250.33 \\
(\mathrm{SD}=40.93)\end{array}$ \\
\hline
\end{tabular}

Table 5. Comparison of Body Mass Index (BMI) values $(\mathrm{Kg} / \mathrm{m} 2)$ in different groups

\begin{tabular}{|c|c|c|c|c|c|c|}
\hline \multirow[t]{2}{*}{ Group } & \multicolumn{2}{|c|}{$\begin{array}{l}\text { OCP } \\
(n=8)\end{array}$} & \multicolumn{2}{|c|}{$\begin{array}{l}\text { Control } \\
(\mathrm{n}=5)\end{array}$} & \multicolumn{2}{|c|}{$\begin{array}{c}\text { Total } \\
(n=13)\end{array}$} \\
\hline & $\begin{array}{c}\text { Before } \\
\text { the intervention }\end{array}$ & $\begin{array}{c}\text { At the end } \\
\text { of intervention }\end{array}$ & $\begin{array}{c}\text { Before } \\
\text { intervention }\end{array}$ & $\begin{array}{l}\text { At the end of } \\
\text { intervention }\end{array}$ & $\begin{array}{c}\text { Before } \\
\text { intervention }\end{array}$ & $\begin{array}{l}\text { At the end of } \\
\text { intervention }\end{array}$ \\
\hline Body Mass & 21.72 & 21.60 & 22.06 & 22.67 & 21.85 & 22.01 \\
\hline Index & $\mathrm{SD}=1.60$ & $\mathrm{SD}=1.13$ & $\mathrm{SD}=3.59$ & $\mathrm{SD}=5.70$ & $\mathrm{SD}=2.41$ & $\mathrm{SD}=3.45$ \\
\hline
\end{tabular}

There was no significant difference between body mass index (BMI) values of the 2 groups before and after the treatment course (Table 5).

\section{Discussion}

The present study revealed some positive effects of OCP on BMD and cardiovascular markers in athletes with FHMD. VLDL $(p=0.035)$ and apo B $(p=0.04)$, whose high levels are predictors of cardiovascular disease, were significantly reduced in the OCP group. Although there was no significant change in BMD values after a 9-month OCP course, BMD values at lumbar spine revealed an increase of $0.3 \%$ in those receiving OCP and a minor decrease of $1.6 \%$ in the control group in 9 months.

Cobb et al. found that the BMD of spinal vertebrae and the entire body of runners with amenorrhea or oligorrhea who had taken OCP for at least 6 months was greater than those runners who had not received any treatment for these disorders. This association was independent of weight or bodily figure. The effect on the annual density factor was estimated at approximately $1 \%$ increase; and effectiveness wise, it was similar to the regaining of menstrual periods or $5 \mathrm{~kg}$ increase in weight (24). Although in our study, BMD values at lumbar spine showed an increase of only $0.3 \%$ in 9 months in those receiving OCP, a considerable decrease of $1.6 \%$ occurred in the control group, which indicates that OCP may prevent decreasing BMD values in athletes with FHMD.

On the contrary to our results, Rickenland et al. reported significantly increased BMD values at lumbar spine in the athletes with oligomenorrhea treated with OCP for a similar duration as our study (10-month)(25). Liu and Lebrun conducted a systematic review to assess the effects of OCP and hormone replacement treatment on pre- and premenopausal women (26). From among the 10 studies published in this regard, 7 (2 RCTs and 5 cohorts) showed positive effects of OCP and other hormone replacement treatments on females with oligo/amenorrhea. Two other studies (a RCT and a cohort) reported the treatment to be ineffective and a single research announced its negative influence on BMD values (26).Chronic estrogen deficien- cy in Turner syndrome has adverse bone and cardiovascular effects. Hence, long-term estrogen replacement therapy is used in treatment. A systematic review and metaanalysis on the effect of estrogen replacement therapy (ERT) on 771 Turner syndrome patients aged younger than 40, who suffered from chronic hypoestrogenism, was conducted. The results suggested the possible beneficial effects of ERT on raising BMD and HDL cholesterol (27). Although weight bearing activities are suggested for the treatment of low BMD, the Female Athlete Triad Coalition Panel is concerned that high impact exercises could result in fracture among female athletes with low BMD. Moreover, oestrogen may be necessary for the osteogenic effects of mechanical loading, but based on the present research, mechanical loading has a poor osteogenic effect on chronically amenorrhoeic athletes. Therefore, it seems that ERT could help increasing BMD through raising the effect of mechanical loading among these athletes $(2,3)$. Elsewhere, a randomized double blind study investigated the effect of hormone therapy on postmenopausal athletes. According to the results, bone resorption was reduced, but bone formation did not increase. Thus, it was concluded that in combination with high impact exercise, hormone therapy can help lower the risk of osteoporosis and its associated fractures (28). On the other hand, the application of hormone therapy in treating menstrual disorders and low BMD has been inconclusive in the athletic population to date.

Our study revealed that OCP positively affects lipid profile. There was a significant decrease in VLDL levels and apo B levels in the OCP group. These pills, on the other hand, resulted in a nonsignificant increase in LDL levels. There was no significant change in HDL and TG levels of either group.

The levels of apo A and HDL, which play a protective role in cardiovascular diseases, were lower than the normal range in $53 \%$ and $38 \%$ of female athletes in our study. This finding is important as we believe that doing regular exercise could increase these 2 factors. Moreover, low levels of these factors are associated with increased risk of developing cardiovascular disease. While there was no 
significant change in apo A levels in the OCP group, their apo B levels reduced significantly. As for the control group who received $\mathrm{Ca}$ and vitamin $\mathrm{D}$ as the sole treatment medication, a significant increase was noted in apo A levels.

In our study, a significant decrease was obtained in VLDL levels of the OCP group. High levels of VLDL $(>30 \mathrm{mg} / \mathrm{dL}$ or $>0.77 \mathrm{mmol} / \mathrm{L})$, similar to $\mathrm{LDL}$, are a risk factor for cardiovascular disease and stroke (29). Increasing levels of VLDL indicate the presence of lipoprotein remnants, intermediate components in the known pathway of conversion of VLDL to LDL. In the presence of high levels of VLDL, the VLDL to LDL conversion trend slows down, causing the aggregation of intermediate components, the development of atherosclerosis, and cardiovascular disease. The fact that $53 \%$ of our study population had VLDL level higher than 30 at baseline and that there has been a significant decrease in its levels after the intervention in the OCP group confirms the consumption of OCP in treating oligomenorrhea in athletes.

The AMORIS trial, a 10-year study on 1111 individuals, showed ApoB/ApoA ratio is a strong predictor of future stroke and myocardial infarction (29). The Interheart study in 2004, conducted on acute MI risk factors in 52 countries, reported that apo A to apo B ratio is the most important risk factor all over the globe (30). As a result, we studied this factor along with the regular lipid profile to assess the cardiovascular status of the athletes. Our study revealed a significant decrease in the apoB/apoA ratio after intervention in both groups. This fact that these changes have occurred in both groups and there was no significant difference between groups may indicate the role of $\mathrm{Ca}$ and vitamin $\mathrm{D}$, which were utilized in both groups in this regard. Some of the previous studies have also reported the positive role of $\mathrm{Ca}$ and vitamin $\mathrm{D}$ on the apolipoprotein levels. Major et al. reported that the consumption of $\mathrm{Ca}$ in a weight loss study had resulted in a reduction in LDL levels and LDL/HDL ratio, independent of the individual's fat mass and waist circumference (31).

Contrary to our results, Rickenuld reported unfavorable changes in lipid profile after OCP consumption. He also reported high apo B and LDL levels in the group with amenorrhea compared with those who had a normal menstrual cycle. Reduced HDL levels were reported in all the 3 groups after treatment. Apo B levels, however, increased (25).

About $23 \%$ of the studied individuals had HbA1c levels equal to 6 , which was not associated with increased FBS levels, indicating a possible association among hypoestrogenemia, insulin resistance, and glucose intolerance. Some studies have revealed that becoming menopause is linked with increased risk of developing glucose intolerance and Type 2 diabetes, considering hypoestrogenism as the main factor in this regard (19). Glucose intolerance, decreased insulin sensitivity, and hyperinsulinemia result in increased glucose levels and elevated CAD risk (20). Several studies have reported that hormone replacement therapy (HRT) in menopausal women may increase insulin sensitivity and glucose tolerance (21). In our study, however, estrogen treatment has no effect on HbAlc and FBS lev- els. This is in line with the research by Okada et al., which was conducted on 200 menopause women, that showed HRT had no effect on HbAlc levels after age and BMI adjustment (23).

\section{Limitation}

Small sample size in our study and the small number of female professional athletes in Iran contributed to the limitations in studying this group of athletes. Moreover, it was not possible to recruit new participants as the study was a continuation of our previous research.

The study duration was about 9 months which according to previous studies is the shortest time needed for any change in bone mineral density values to become apparent. Due to the fact that female athletes participating in our study had been suffering from menstrual irregularities (amenorrhea/oligomenorrhea) for at least 2 years, they might need longer period of treatments to display significant changes in BMD values and some laboratory factors.

\section{Recommendations}

1. The link between the development of cardiovascular health related complications such as lipid disorders and long-term menstrual disorder in the athletes points out the need for more evaluation of impaired lipid profile and insuline resistance in the athletes with menstrual disorders.

2. Long-term studies are needed to evaluate cardiovascular health in athletes with FHMD.

3. Further studies with larger sample sizes are required to determine the long-term effect of estrogen and its side effects in athletes with FHMD.

\section{Conclusion}

In conclusion, although the administration of estrogen has no effect on increasing the bone density significantly, it has positive effects on the cardiovascular system and lipid profile, specially reduced VLDL and apo B, whose high levels are predictors of cardiovascular disease.

\section{Acknowledgement}

The authors thank Dr. Farhad Shahram and Dr. Bahar Sadeghi, and Ms. Haleh Gholami for their valuable insights. Also, the authors wish to thank the Clinical Research Development Center of Rasoul-e-Akram hospital. This study was partly presented in the dissertation of the corresponding author (GH.S) in Rasoul-e-Akram hospital in Iran University of Medical Sciences (Grant No: 927/ب).

\section{Conflict of Interests}

The authors declare that they have no competing interests.

\section{References}

1. Nattiv A, Loucks AB, Manore MM, Sanborn CF, Sundgot-Borgen J, Warren MP. American College of Sports Medicine position stand. The female athlete triad. Med Sci Sports Exerc 2007;39(10):1867-82.

2. Joy E, De Souza MJ, Nattiv A, Misra M, Williams NI, Mallinson RJ, et al. 2014 Female athlete triad coalition consensus statement on treatment and return to play of the female athlete triad. Curr Sports Med Rep 2014;13(4):219-32. 
3. De Souza MJ, Nattiv A, Joy E, Misra M, Williams NI, Mallinson RJ, et al. 2014 Female Athlete Triad Coalition Consensus Statement on treatment and return to play of the female athlete triad: 1st International Conference held in San Francisco, California, May 2012 and 2nd International Conference held in Indianapolis, Indiana, May 2013. Br J Sports Med 2014;48(4):289-.

4. Mountjoy M, Sundgot-Borgen J, Burke L, Carter S, Constantini N, Lebrun C, et al. The IOC consensus statement: beyond the Female Athlete Triad--Relative Energy Deficiency in Sport (RED-S). Br J Sports Med 2014;48(7):491-7.

5. Dadgostar H, Razi M, Aleyasin A, Alenabi T, Dahaghin S. The relation between athletic sports and prevalence of amenorrhea and oligomenorrhea in Iranian female athletes. Sports Med Arthrosc Rehabil Ther Technol 2009;1(1):16.

6. Movaseghi S, Dadgostar H, Dahaghin S, Chimeh N, Alenabi T, Dadgostar E, et al. Clinical manifestations of the female athlete triad among some Iranian athletes. Med Sci Sports Exerc 2012;44(5):95865.

7. Goolsby MA, Boniquit N. Bone Health in Athletes The Role of Exercise, Nutrition, and Hormones. Sports Health: A Multidisciplinary Approach. Sports Health 2017;9(2):108-117.

8. Looker AC, Borrud LG, Dawson-Hughes B, Shepherd JA, Wright NC. Osteoporosis or low bone mass at the femur neck or lumbar spine in older adults: United States, 2005-2008. NCHS data brief 2012;93(18.5).

9. Liu S, Lebrun C. Effect of oral contraceptives and hormone replacement therapy on bone mineral density in premenopausal and perimenopausal women: a systematic review. Br J Sports Med 2006;40(1):11-24.

10. Mallinson RJ, Williams NI, Gibbs JC, Koehler K, Allaway HC, Southmayd E, et al. Current and past menstrual status is an important determinant of femoral neck geometry in exercising women. Bone 2016;88:101-12.

11. Rauh MJ, Macera CA, Trone DW, Shaffer RA, Brodine SK. Epidemiology of stress fracture and lower extremity overuse injury in female recruits. Med Sci Sports Exerc 2006;38(9):1571-7.

12. O'Donnell E, De Souza MJ. The cardiovascular effects of chronic hypoestrogenism in amenorrhoeic athletes: a critical review. Sports Med 2004;34(9):601-27.

13. Soleimany G, Dadgostar H, Lotfian S, Moradi-Lakeh M, Dadgostar E, Movaseghi S. Bone Mineral Changes and Cardiovascular Effects among Female Athletes with Chronic Menstrual Dysfunction. Asian J Sports Med 2012;3(1):53-8.

14. Steinberg D. Lipoproteins and the pathogenesis of atherosclerosis. Circulation 1987;76(3):508-14.

15. Mendelsohn ME, Karas RH. The protective effects of estrogen on the cardiovascular system. N Engl J Med 1999;340(23):1801-11.

16. O'Connell BJ, Genest J, Jr. High-density lipoproteins and endothelial function. Circulation 2001;104(16):1978-83.

17. Balika Iu D, Chernukha GE, Kuznetsov S, Benediktova AB. The lipid composition of the blood serum in certain forms of ovarian amenorrhea. Akush Ginekol (Mosk) 1990(9):52-5.

18. Lamon-Fava S, Fisher EC, Nelson ME, Evans WJ, Millar JS, Ordovas JM, et al. Effect of exercise and menstrual cycle status on plasma lipids, low density lipoprotein particle size, and apolipoproteins. J Clin Endocrinol Metab 1989;68(1):17-21.

19. Wu SI, Chou P, Tsai ST. The impact of years since menopause on the development of impaired glucose tolerance. J Clin Epidemiol 2001;54(2):117-20.

20. Fontbonne AM, Eschwege EM. Insulin and cardiovascular disease. Paris Prospective Study. Diabetes Care 1991;14(6):461-9.

21. Nabulsi AA, Folsom AR, White A, Patsch W, Heiss G, Wu KK, et al. Association of hormone-replacement therapy with various cardiovascular risk factors in postmenopausal women. The Atherosclerosis Risk in Communities Study Investigators. N Engl J Med 1993;328(15):1069-75.

22. Gevers Leuven JA. Sex steroids and lipoprotein metabolism. Pharmacol Ther 1994;64(1):99-126.

23. Okada M, Nomura S, Ikoma Y, Yamamoto E, Ito T, Mitsui T, et al. Effects of postmenopausal hormone replacement therapy on $\mathrm{HbA}(1 \mathrm{c})$ levels. Diabetes Care 2003;26(4):1088-92.

24. Cobb KL, Bachrach LK, Sowers M, Nieves J, Greendale GA, Kent $\mathrm{KK}$, et al. The effect of oral contraceptives on bone mass and stress fractures in female runners. Med Sci Sports Exerc 2007;39(9):146473.
25. Rickenlund A, Carlstrom K, Ekblom B, Brismar TB, Von Schoultz B, Hirschberg AL. Effects of oral contraceptives on body composition and physical performance in female athletes. J Clin Endocrinol Metab 2004;89(9):4364-70.

26. Liu SL, Lebrun CM. Effect of oral contraceptives and hormone replacement therapy on bone mineral density in premenopausal and perimenopausal women: a systematic review. Br J Sports Med 2006;40(1):11-24.

27. Cintron D, Rodriguez-Gutierrez R, Serrano V, Latortue-Albino P, Erwin PJ, Murad MH. Effect of estrogen replacement therapy on bone and cardiovascular outcomes in women with turner syndrome: a systematic review and meta-analysis. Endocrine 2017;55(2):366-375.

28. Honisett SY, Pagliaro D, Tangalakis K, Kingwell B, Ebeling P, Craven $\mathrm{R}$, et al. Hormone therapy reduces bone resorption but not bone formation in postmenopausal athletes. Pril (Makedon Akad Nauk Umet Odd Med Nauki) 2016;37(2-3):15-21.

29. Walldius G, Jungner I, Holme I, Aastveit AH, Kolar W, Steiner E. High apolipoprotein B, low apolipoprotein A-I, and improvement in the prediction of fatal myocardial infarction (AMORIS study): a prospective study. Lancet 2001;358(9298):2026-33.

30. Yusuf S, Hawken S, Ounpuu S, Dans T, Avezum A, Lanas F, et al. Effect of potentially modifiable risk factors associated with myocardial infarction in 52 countries (the INTERHEART study): case-control study. Lancet 2004;364(9438):937-52.

31. Major GC, Alarie F, Dore J, Phouttama S, Tremblay A. Supplementation with calcium + vitamin D enhances the beneficial effect of weight loss on plasma lipid and lipoprotein concentrations. Am J Clin Nutr 2007;85(1):54-9. 